\title{
Richard Luchsinger to His 80th Birthday
}

In 1970 we commemorated Prof. Richard Luchsinger's 70th birthday in Folia Phoniatrica, and today we have the pleasure of celebrating his 80th. He was born in Glarus (Switzerland) on June 14, 1900. He studied medicine in Basel; in 1932 he started to dedicate himself to voice and language disorders. He led a clinic in Zurich, from where he spread his knowledge which aroused the interest of many European colleagues who followed his teaching. In 1949 he published a book with G.E. Arnold entitled Lehrbuch der Stimm- und Sprach-heilkunde from which many physicians studied phoniatrics. This book has had many editions, the last of which is an English translation published in the USA in 1966, and continues to be a manual of great value.

The scientific value of Prof. Luchsinger's work has been affirmed by his numerous contributions at meetings and international congresses.

Richard Luchsinger to His 80th Birthday

156

Due to his merits, he was elected President of the International Association of Phoniatrics and Logopedics (1953-1959), a great honor that shows the esteem in which phoniatricians all over the world hold him.

After World War II, together with Tarneaud and Seeman, he founded Folia Phoniatrica, an international review which is acquiring more and more prestige annually.

In the name of Folia Phoniatrica, of the IALP, and of all the phoniatricians all over the world, I have the honor of greeting Prof. Luchsinger on his birthday and of showing him our deep and sincere regard.

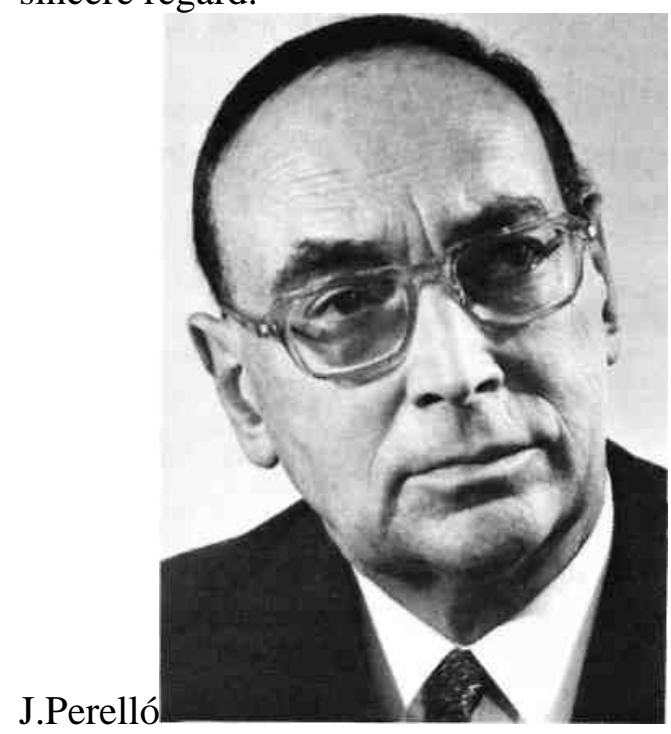

